\title{
Ideologi styrer Irans udenrigspolitik
}

\section{Mehdi Mozaffari}

Irans forfatning viser et totalitært regime, som sætter islam over nationens interesser i udenrigspolitikken og kræver ydre fjender for regimets overlevelse. Forfatningen er Hassan Rowhani også bundet af, selv om den nye præsident lover forsoning med omverdenen. Denne artikel omhandler den lange historie før Rowhani

Siden den islamiske revolution $\mathrm{i}$ 1979 har Iran været genstand for en imponerende mængde studier af næsten alle aspekter af iransk liv. Iransk udenrigspolitik har ikke været en undtagelse fra denne enorme interesse. Arbejder inden for det felt er så talrige, at de ikke kan nævnes her. Alene om atomspørgsmålet er en massiv og varieret litteratur allerede tilgængelig. Men vi må anerkende utilstrækkeligheden i nogle solide akademiske arbejder, når det gælder teoretiske forklaringer, der gør hele atomsagen forståelig.

I denne forbindelse er professor Djalili blandt de første akademikere, der har fokuseret på ideologiens kritiske rolle i iransk udenrigspolitik
(Mohammad-Reza Djalili: Strategie international de khomeynisme, Paris 1989). Mere end to årtier efter udgivelsen er ideologiens rolle i iransk udenrigspolitik så tydelig som nogensinde.

I dag udgør Iran en yderst kontroversiel aktør, regionalt og internationalt. Den politik, som er ført af tandemet Khamenei-Ahmadinejad er stærkt bekymrende for FN, Det Internationale Atomenergiagentur (IAEA) såvel som for den yderst følsomme region omkring Iran.

En række spørgsmål rejser sig som, hvorfor det er så svært, ja noget nær umuligt, at nå en form for forståelse, en form for kompromis med Iran om forhold som atompro- 
grammet eller om baggrunden for Irans indgroede fjendtlighed over for selve Israels eksistens.

Ved at vælge 'ideologi' frem for 'nationale interesser' som den vigtigste faktor, kommer vedholdende mønstre op til overfladen i iransk udenrigspolitik.

Den præcise tese i dette studium er følgende: Den Islamiske Republik Iran, IRI's udenrigspolitik er styret af en totalitær ideologi snarere end af nationale interesser.

\section{Allahs vilje}

Denne antagelse er støttet af en sammenhængende serie kendsgerninger, der går fra diskurs til symbolisme, fra institutionalisering til beslutninger og handlinger. I

IRI har ideologi en religiøs karakter, der både styrker den mytiske dimension og fritager beslutningstagere fra rationel argumentation. 'Det er Allahs vilje' og 'Det er, hvad islam ønsker', bruges ofte som argumentation. Den ideologiske karakter er stadfæstet i forfatningen, hvori det hedder:

"Forfatningens formål er at virkeliggøre Revolutionens (Nehzat) mål og skabe betingelser, der fremmer menneskets udvikling i overensstemmelse med islams noble og universelle værdier". (uddrag af præamblen).

Irans forfatning er et fremragende instrument til at studere de mest fundamentale træk ved det iranske islamiske regime. I dokumentet findes regimets verdenssyn, principielle opfattelser og lejlighedsvise opfattelser, alt sammen i samme dokument. Men i hvilket omgang har den iranske forfatning validitet?

Det er et legitimt spørgsmål på baggrund af, at landene i Mellemøsten, som har en forfatning, der udstikker principper som menneskerettigheder og frie valg, normalt krænker de selv samme principper. Desuden husker iranere stadig den manglende iværksættelse - eller åbne krænkelse - at forfatningen under shahens regime.

Den nuværende situation er ret anderledes af en simpel grund. Forfatningen af 1906, der formelt set gjaldt indtil revolutionen i 1979, gjorde direkte shahens absolutisme illegitim, og som konsekvens heraf krænkede han systematisk den forfatning. Der var også gentagne krav fra forskellige oppositionsgrupper i perioden før 1979 om fuld effektuering af forfatningen (ejra-ye qanun-e asasi).

I dag er forfatningen, der er baseret på en ideologiseret religion ført fuldt ud i livet og allokerer legitimitet til religiøse eliter og deres ledelse, lige som den udstyrer dem med reel magt. Derfor har grupperne ved magten fået en direkte interesse $i$ at gennemføre forfatningen.

At krænke eller marginalisere forfatningens forskrifter vil være politisk selvmord. I den islamistiske forfatning er alle og enhver rettighed i 
overensstemmelse med religion, og afgørelser i sådanne sager er allokeret til udpegede religiøse myndigheder.

Det vigtigste i forfatningens præambel er 'islams noble og universelle værdier', ikke 'nationale værdier' eller 'Irans nationale interesser'? Og hvem har myndighed til at beslutte, om 'islam' eller 'Iran' har forrang? For islam og Iran er ikke altid identiske størrelser eller i harmoni med hinanden.

\section{Eksemplet Israel}

Lad os tage et konkret eksempel: Israel. Det er klart, at IRI fra dag et har ført en meget fjendtlig og aktivistisk politik imod Israels blotte eksistens. Er denne politik nødvendig for at sikre Irans nationale interesser?

Jeg tror ikke, at der er behov for nogen længere argumentation for at slå fast, at det ikke er tilfældet. Tværtimod har både Iran og Israel en objektiv interesse $\mathrm{i}$ at undgå konflikter med hinanden, da de begge har været og stadig er i konflikt med nogle arabiske lande.

Derfor må vi finde motivationen for IRI's vedholdende fjendtlighed over for Israel i udenrigspolitikkens ideologiske karakter, som er fremmed over for begrebet 'nation' og 'national interesse', der ikke er anerkendt som det primære mål.

Retfærdiggørelsen af den aktive animositet imod Israel sker derfor med ikke-nationale argumenter som 'Israel er muslimernes fjende', Palæstina er 'islamisk territorium' osv.

\section{Islamisk umma}

Ideologisk er det iranske regime baseret på begrebet islamisk Umma (ommat-e eslam) og ikke på den iranske nation (mellat-e Iran). Iranske ledere taler sjældent om Iran i neutrale toner, men forbinder det som regel med islam, Iran-e eslami (islamisk Iran), mihan-e eslami, vatan-e eslami (islamisk hjemland) osv. .

Det iranske regimes præ-westfalske karakter er i realiteten en reminiscens af den klassiske islamiske stat, hvis grundlag "var ideologisk, ikke politisk, territoriel eller etnisk, og regeringens primære formål var at forvare og beskytte troen, ikke staten" (Ann K.S. Lambton: State and government in Medieval Islam, Oxford 1981).

Iran passer perfekt til afdøde professor Lambtons beskrivelse, hvor regimet netop alene er baseret på troen på islam, ikke på nationen, som det gøres klart i præamblen til forfatningen.

Under de seneste over 30 år, hvor khomeinisterne har været ved magten i Iran, har der været ikke så få direkte forsøg, opmuntringer eller støtte fra deres siden på systematisk at svække den iranske identitet. I revolutionens start var der krav om udslettelse (sic!) af Persepolis, forbud imod at spille den iranske national- 
hymne, afskaffelse af Nowruz (det iranske nytår) og forsøg på at erstatte det med en shiitisk dag (al-Ghadir) osv. .

De iranske hærenheder blev om$\mathrm{d} ø b t$ til islamiske navne som ' $\mathrm{Mu}$ hammad, Rasul Allah' og 'Zulfiwar' (Imam Alis sværd). Mange universiteter blev opkaldt efter shiitiske imamer som Imam Ja'far Sadeq Universitet eller al-Zahra Universitetet for kvindelige studerende.

Det er imidlertid sandt, at vi efter at Ahmadinejad kom til magten, har været vidner til en langsom men fremadskridende tendens i retningen af iransk nationalisme. Denne tendens var mærkbar i Ahmadinejads taler, hvor termer som 'mellat' nation og Iran uden det sædvanlige præfiks forekom med øget frekvens.

Ahmadinejads nationalistiske tendens er imidlertid ikke en volte-face eller en erstatning af hans stærke islamiske overbevisning. Han er forblevet en brændende forsvarer for islam og muslimer, som han ofte selv hævder. Han har endog proklameret et et-partisystem ved at sige, at "den islamiske republik har kun et enkelt parti velayat" (et vagt begreb, som både henviser til Lederen og til shiitiske imamer).

Den nye udvikling i den proces lå i nationalisme som baggrundsmusik, der indikerede eksistensen af noget forskelligt fra den islamiske ideologi - men ikke som en autonom kategori eller identitet, snarere som pendant til den islamiske identitet, som præsenteres som den sande og autentiske identitet.

Hvis antagonismen mellem den stadig stærkere Revolutionsgarde (IRGC) på den ene side og det shiitiske præsteskab på den anden skærpes i fremtiden, kan IRGC altid bruge det nationalistiske kort som alternativ til præsteskabets legitimitet.

\section{Spændinger øges}

I løbet af 2011 blev konfrontationen mellem Ahmadinejad og Khamenei direkte og tydelig. Det stod klart, da Ahmadinejad pludselig fyrede efterretningsministeren uden at have informeret det magtfulde Bayt-e Rahba$r i$, Khameneis kontor. Lige som udenrigsministeriet hører efterretningsministeriet traditionelt under Khameneis domaine réservé som øverste leder.

Khamenei så det som en krigserklæring, som krævede et hurtigt, offentligt og direkte svar, så Khamenei genudnæunte den samme Heydar Moslehi til samme funktion.

Det var selvfølgelig en ydmygelse af Ahmadinejad, og den magtkamp afslørede to ting: For det første at konfrontationen i toppen af magtpyramiden er reel. For det andet at Revolutionsgarden er delt imellem det, som groft sagt kan kaldes 'moderate' og 'radikale'. De moderate, som også er de rigeste og mest privilegerede, støttede Khamenei, mens de radikale, især Basij (paramilitært frivilligt korps) var for Ahmadinejad. 
Efter denne kamp fandt Ahmadinejad det nødvendigt at nedtone sin nationalisme. Det bekræfter, at hans brug af nationalisme var baseret på et opportunistisk snarere end et autentisk tilhørsforhold til iransk nationalisme.

Lad os nu sætte fokus på det islamiske regimes totalitære karakter. Jeg vil gøre det klart, at med 'totalitarisme' mener jeg regimet ved magten og ikke samfundet som sådan. Det er velkendt, at intet samfund bliver fuldstændig totalitært.

Et af de bedste eksempler på IRI's totalitære karakter findes i forfatningens artikel 4:

"Al civil, strafferetslig, finansiel, $ø$ konomisk, administrativ, kulturel, militær, politisk og andre love og reglementer er baseret på islamiske kriterier. Dette princip gælder absolut og generelt til alle forfatningens artikler og Vogternes Råds fuqaha (religiøs retfærdighed) dømmer i disse forhold".

Regimets totalitære karakter styrkes af institutionaliseringen af en religiøs ledelse, som har den totale magt (artikel 110, forfatningens længste artikel).

\section{De evige fjender}

Et andet totalitært træk er tilstedeværelsen af evigt eksisterende fjender, der konstant konspirerer imod in casu Iran.

I totalitære regimer er situationen aldrig normal; undtagelsestilstand er reglen, som regimerne retfærdiggør deres beslutninger og handlinger med. Derfor må totalitære regimer skabe og vedligeholde 'kriser'. At skabe kunstige kriser bliver derfor en regeringsstil, som tilfældet er i det iranske regime.

Gidseltagningen i den amerikanske ambassade i Teheran (4. nov. 1979) var en helt igennem fremprovokeret krise.

Forlængelsen af krigen med Irak, efter Iraks forslag om våbenhvile $i$ 1982, var også.

Rushdie affæren i 1989 og den konstante fjendtlighed over for Israel var alene motiveret af behovet for en fjende. Og at føre en fordømmende og gennemført ambivalent politik på det yderst farlige atomenergiområde demonstrerer igen det næsten vitale behov i det islamiske regime for kriser.

"Igen og igen høres råbet, at en eller anden overordnet aftale må nås, gennem topmøde eller traditionelt diplomati. At appellere til fred og samtidig gøre alt for at forhindre, at den 'bryder ud' er et nøgletræk i relationerne mellem totalitære diktaturer og omverdenen".

Det skrev Zbigniew Brzezinski og Carl J. Friedrich i 1965. Årtier med mislykket dialog for at komme til forståelse med det iranske regime har til fulde bekræftet rigtigheden af de linjer.

Totalitære regimer giver kun efter for alvorligt pres. Det iranske regime har ved nogle lejligheder accep- 
teret resultater, som det ikke foretrak.

I 1990 blev Saddam Husseins angreb på Iran hyldet af Khomeini som 'en guddommelig gave' ( $n e$ ' mat-e lahi), men det viste sig at blive 'et bæger gift', (jam-e zahr), som Khomeini måtte drikke med accept af FN-resolution 598 10. juli 1987 og den efterfølgende våbenhvile (aug. 1988).

Vi så det samme i Rushdie-affæren. Stillet over for en enstemmig beslutning fra de da 12 medlemmer af EU om at hjemkalde deres ambassadører fra Teheran, erklærede den iranske udenrigsminister, at regeringen ikke vil forsøge at tage Rushdies liv.

Suspenderingen af Irans uranberigelsesprogram i 2003 er endnu et eksempel. Ifølge US Intelligence Councils rapport i november 2007 er der indikationer på, at Iran suspenderede det militære aspekt af atomprogrammet i 2003.

Hvis det kan verificeres, indikerer det klart iranske forsøg på at føre en præventiv politik for at undgå at blive sat under ubærligt pres, måske endog militær aggression.

I alle tre tilfælde var pres den virkelig årsag til ændring i Irans holdninger. I det første tilfælde tvang udmattede ressourcer Khomeini til at afslutte krigen med Irak. I de andre to tilfælde var stærkt internationalt pres og frygt for gengældelse de afgørende faktorer for at ændre iransk politik.

\section{Tilfælde af forsigtighed}

Det er også værd at bemærke, at IRI faktisk har ført en forsigtig politik i nogle geografiske områder og over for nogle bestemte stater.

Det er tilfældet i Kaukasus, hvor Iran ikke støttede det muslimske oprør i Tjetjenien. Det samme var tilfældet i den armensk-aserbajdsjanske konflikt om Nagornij-Karabakh. Iran førte en mere pro-armensk end pro-aserbajdsjansk politik, trods det faktum, at Aserbajdsjan er et muslimsk land. Iran har heller ikke støtte islamistiske bevægelser i Centralasien.

Forskellige faktorer forklarer denne 'anormalitet'. Irans dengang tætte relationer til Rusland, Aserbajdsjans ambitioner om den iranske provins Aserbajdsjan og den anti-shiitiske karakter af wahhabistiske islamistiske bevægelser i Centralasien er blandt de forhold, der forklarer Irans politik på disse specifikke områder.

Desuden forholder det sig sådan, at totalitære regimer for at styrke sig selv, undgå potentielle farer og sikre sine interesser skaber tætte relationer, selv former for alliancer med ikke-totalitære regimer på den ene betingelse, at de får støtte nok af dem.

Det er sket et antal gange i historien: Stalins alliance med vestlige demokratier imod Hitler, det maoistiske Kinas fremragende relationer til det pro-vestlige Pakistan eller sha- 
hens regime i Iran er eksempler.

At have tætte relationer til ikke-totalitære regimer mindsker ikke et regimes totalitære natur. Totalitære regimer kan være pragmatiske i deres udenrigspolitik uden at negligere hverken deres revisionistiske karakter eller ideologiske mål.

Når det gælder det islamistiske Iran, har dets tæette relationer til det sekulære Syrien såvel som til en række marxistiske ledere i Latimamerika ikke på nogen måde påvirket det iranske regimes islamistiske, totalitære og selv anti-sekulære karakter.

Totalitære regimer er revisionistiske i deres udenrigspolitik, som bolsjevisme, nazisme og maoisme alle var. Og revisionisme påvirker det internationale systems strukturer. Khomeinis islamiske revolution udfordrede både USSR (udfordreren) og USA (den udfordrede).

\section{Islamisk imperialisme}

IRI's revisionistiske karakter har medført en anti-imperialistisk imperialisme. Målet er ikke at gøre en ende på imperialisme, men at erstatte vestlig imperialisme med et nyt islamisk hegemoni som en reminiscens af den islamiske verdensmagts gyldne tidsalder.

Denne kurs har skabt en mærkværdig alliance med alle slags ekstremister, bare de bekæmper det eksisterende internationale system.

Det iranske regime har allieret sig med både det ekstreme venstre og ekstreme højre på globalt plan som Hugo Chávez og Ku Klux Klan på en og samme tid.

Til at opnå målet 'et verdensfællesskab' har Lederen/Rahbar en 'ideologisk' hær (artesh-e maktabi) til sin rådighed. I klar tale er militær jihad en forfatningssikret pligt for Irans hær. Det hedder i forfatningen: "Dannelse og udrustning af landets forsvarsstyrker skal ske i nøje overensstemmelse med tro og ideologi som de grundlæggende kriterier".

For at realisere ambitionen om et islamisk imperium har IRI ikke bare brug for ressourcer men også to andre elementer: at erobre en prestigeombrust islamisk by og fabrikere atomvåben.

For tiden er Jerusalem så at sige den eneste mulige by til rådighed. At sige at Jerusalem er Irans mål lyder urealistisk og er måske også et utopisk mål. Men vi har gentagne gange set i historien, at det ikke reducerer vigtigheden af utopi i et totalitært regime eller den fare, som det indebærer for en regions sikkerhed.

Det er en kendsgerning, at Iran har en række vigtige favorable faktorer, herunder den geografiske placering imellem Kaukasus og Centralasien mod nord og Den Persiske Golf mod syd. Det har en relativ ung befolkning på over 70 millioner og massive reserver af gas (de næststørste i verden) og olie (de tredjestørste i verden). Iran har også opnået 
betragtelig popularitet i den arabiske verden, hvilket kan ses som Irans soft power.

Men Irans ambitioner støder på alvorlige hindringer, ikke kun i form af andre muslimske lande som Saudi- Arabien, Pakistan, Egypten og Tyrkiet, der har lignende drømme. Der er også vanskeligheder af en anden karakter.

For det første er Iran et shiitisk land, mens det store flertal af verdens muslimer er sunni'er (omkring 90 procent). Det shiitiske Iran kan måske engang i fremtiden blive centrum for et shiitisk imperium, men ikke for et islamisk imperium.

Iranske ledere har prøvet at nedtone deres shiitiske tilhørsforhold fra revolutionens første dag. Khomeini henvendte sig systematisk til alle muslimer og så sig selv som øverste leder for hele den muslimske verden.

Den nuværende øverste leder Khamenei hæuder, at Iran ikke ønsker konflikt med sunni-islam, men at USA søger krig med hele den islamiske verden.

Iran står over for en større forhindring: I muslimers opfattelse repræsenterer Iran ikke rigtig et prestigefyldt islamisk land.

Teheran er en relativt ny og ordinær by, intet i nærheden af Mekka, Medina, Bagdad, Damaskus, Kairo eller Istanbul. De to hellige byer i Iran, Mashdad og Qom, er kun hellige ifølge tilhængere af de tolv shiitiske imamer.

\section{Plan B: Jerusalem}

I revolutionens første år var Khomeinis opmærksomhed primært rettet mod de to mest hellige islamiske byer, Mekka og Medina. Derfor prøvede han at destabilisere den saudiarabiske kongefamilie ved at støtte uroligheder i landet som i forbindelse med saudiske islamisters militære besættelse af Mekkas hellige moske (20. nov. 1979) og ved at fremprovokere blodige demonstrationer under hajj, pilgrimsfærd.

Parallelt med disse initiativer lavede Khomeini en Plan B: Erobring af Jerusalem. Under Iran-Irak krigen (1980-88) mindede Khomeini ofte iranerne om, at 'vejen til Jerusalem går gennem Karbala'. Det var en klar indikation på, at det virkelige mål ikke så meget var at slå Irak som erobring af Jerusalem.

Når vi dykker dybere ned, opdager vi, at IRI ikke så meget er for en palæstinensisk stat, men det virkelig mål er at udslette Israel. De to mål er ikke nødvendigvis sammenfaldende.

Iran støtter kun palæstinensiske fraktioner, som arbejder for udslettelse af den jødiske stat. Hamas' ledere inviteres til Teheran, ikke lederne af den palæstinensiske autonome myndighed. Iran er ikke propalæstinensisk, men anti-israelsk for enhver pris. Og 'udslettelsen' af Israel har kun et mål: kontrol med Jerusalem.

Den samme hegemonistiske logik 
forklarer de hidtil urokkelige iranske ambitioner om at opnå atomkapabilitet. I atomalderen er det helt udelukket, at et nyt islamisk imperium kan skabes uden det ultimative våben.

Sagen er imidlertid ikke, at Iran kan bruge atomvåben imod Israel. Udelukkelsens logik vil afholde Iran herfra, hvis ikke iranerne er villige til at acceptere selvudslettelse.

Det er prestigen ved at have atomvåben, som er interessant for et land, der har ambitioner om at blive centrum for en islamisk verdensmagt. Det er ret interessant, at ayatollah Khamenei og andre iranske ledere har diffentieret mellem 'besiddelse' og 'udstationering' af atomvåben. I islam er 'udstationering' (este 'mal) af atomvåben forbudt, men regimet er tavst om 'besiddelse' (dashtan).

\section{Fndring mulig?}

Siden 1979-revolutionen har verden set dramatiske forandringer. Selv det iranske samfund er ændret: nye klasser er dukket frem, iranske unge - kvinder som mænd - presser på for åbning til den moderne verden og for kulturel pluralisme. Den kulturelle skizofreni er blevet evident. Trods de mange ændringer er det iranske regime (stadig forskellig fra samfundet) forblevet næsten, som det var under Khomeini.

Er det realistisk at forvente, at Iran kan lægge betydningsfuld afstand til dets ideologiske rødder i et forsøg på at blive en 'normal' stat? Under hvilke omstændigheder vil det islamiske regime revidere sin revolutionære, revisionistiske, totalitære og præ-westfalske udenrigspolitik?

Sagen er, at dette ideologisk monolitiske regime ikke er monolitisk i politisk forstand, da forskellige kræfter inden for det politiske system konkurrerer om magten. Groft sagt dem, som kalder sig Principalister (osulgaryan) og dem, som kalder sig Reformister (eslahtalaban).

Fundamentalisterne (høgene) ønsker et stift system, mens reformisterne (duerne) vil introducere en grad af moderation i magtudøvelsen. Men bortset fra det er alle enige om regimets grundlæggende aspekter og ideologiske mål. Der høres stemmer for en mere rationel udenrigspolitik, men de stemmer er ikke stærke nok til at modificere politikkens hovedkurs.

Parallelt med den indre antagonisme mellem fundamentalisterne og reformisterne, er der en muligvis endnu vigtigere antagonisme, som kan få store konsekvenser i fremtiden: Den hidtil usete succes for IRGC, når det gælder at opnå politisk magt gennem 'et krybende statskup'.

\section{De Grønnes opståen}

Over for Ahmadinejads hårde retorik og radikalisering af udenrigspolitikken generelt, havde reformister- 
ne ikke andet valg end at skærpe deres kritik. Splittelsen skete som resultat af Ahmadinejads genvalg i juni 2009. Efter Den Grønne Bevægelses opståen har splittelsen mellem Fundamentalister og Reformister aldrig været så dyb som i dag.

Den Grønne Bevægelse er en slags paraply over forskellige og også modsatrettede fraktioner. Bevægelsens to frontfigurer, Mir-Hossein Mousavi og Mehdi Karroubi (præsidentkandidater), udfordrede ikke det islamiske regime eller dets forfatning. De udfordrede kun den nuværende $\varnothing v e r s t e$ leder Khameneis legitimitet. Han kritiseres for at være leder af en klike og ikke af den islamiske republik, som forfatningen ellers kræver.

Den Grønne Bevægelse har endnu ikke produceret et klart udenrigspolitisk program. Udenrigspolitik er næsten fraværende i Karroubis erklæringer og det hidtil publicerede fra Mousavi om emnet i interviews og kommunikeer har været kryptisk og ambivalent. Man får indtryk af en person, der ser sig som en autentisk khomeinist.

I en mere tematisk og struktureret erklæring, prøvede Mousavi at etablere synergi mellem islamisk og iransk identiteter 'som uadskillelige'.

I samme dokument talte han om "en rationel og værdig udenrigspolitik... med det formål at fremme nationen Iran i verden".

Om atomspørgsmålet forbliver Mousavis holdning tvetydig.

\section{Konklusion}

At vælge ideologi som den vigtigste faktor til at forklare Irans post-revolutionære udenrigspolitik forklarer ikke alt, men det forklarer meget. Over for det westfalske system, repræsenterer det post-revolutionære Iran en anormalitet. Ved konstant at fokusere på sin ideologiske identitet, har Iran dramatisk svækket sin identitet som nationalstat.

Iran står som en aktør, der kæmper for en tro i stedet for at tage sig af de mangesidede opgaver, som en nationalstat normalt beskæftiger sig med: Primært statens overlevelse og sikkerhed. Vigtig er også omsorg for velfærd og økonomisk vækst og magt såvel om bevarelse af nationens kultur. I den forbindelse fremmer mål som 'islams sejr' og 'jihad i Allahs spor' ikke Irans velstand og $ø$ konomiske vækst som nation.

Derfor må man fortolke i forhold til denne tro og ikke det nationale aspekt, når man vil analysere den bogstaveligt talt trofaste stat.

Når implementering af en trosbaseret ideologi bliver statens erklærede mål, vil regimet uundgåeligt være autoritært.

Når det iranske regime åbent og bevidst har gjort islamisme (eller khomeinisme) til statens raison d'etre har det gjort sig til gidsel for sin egen ideologi. Ideologi bestemmer en stats optræden og ikke omvendt. Bolsjevisme, nazisme og maoisme var ikke særligt succesrige med at til- 
passe sig de hårde realiteter og samtidig holde sine respektive ideologier intakte.

Nazityskland ødelagde sig selv sammen med millioner af mennesker.

Kina blev kapitalistisk; det beholdt kommunistpartiet kun som et integrationsinstrument og Maos portræt som en reminiscens af uafhængighed.

Det som sker med Den Islamiske Republik Iran vil formentlig skabe et nyt og hidtil uset scenarium.
Mehdi Mozaffari er professor i islamiske studier ved Institut for Statskundskab, Århus Universitet.

Dette er en forkortet udgave af Mozaffaris bidrag til 17 essays $i$ bogen 'Iran and the Challenges of the Twenty-First Century' redigeret af H.E. Chehabi m. fl. Mazda Publishers 2013. Omtalt i Bognoter, Udenrigs 1. 2013.

'Oversat fra engelsk af Vibeke Sperling'.

Det omfattende noteapparat til Mozaffaris essays kan fås ved henvendelse til BritaV. Andersen: brita@udenrigs.dk 